\title{
The Contribution of Intercultural Psychology to Clinical and Research Projective Assessment Approaches ${ }^{1}$
}

\author{
Elaine Costa-Fernandez \\ Federal University of Pernambuco \\ Zohra Guerraoui \\ University Toulouse Jean Jaurès \\ Gesine Sturm \\ University Toulouse Jean Jaurès \\ Odile Reveyrand-Coulon \\ University of Bordeaux
}

\begin{abstract}
This article discusses the contribution of intercultural psychology to projective evaluation methods in clinical intervention and research. It is part of the intercultural psychology field which supports, at the epistemological level, the intimate constitutive relationship between the contexts of belonging and the always unique development of the psychological subject. In order to understand the specificities and the stakes of this perspective on the projective clinic, we will first analyze the foundations of intercultural psychology, then address the complexity of cultural belonging in the contemporary world, and finally open up new perspectives of projective evaluation both in clinical practice and in research situations.
\end{abstract}

Keywords: intercultural psychology, projective assessment, clinical practice, research

\section{INTRODUCTION}

How can we think about psychological evaluation when most people today are structured in a plurality of cultural references? Are our traditional reading grids sufficient and effective? Shouldn't they be reexamined? What are the epistemological and theoretical foundations on which to rely in order to be able to explore, understand and evaluate psychological functioning in these new situations in our contemporary world? These are questions that have been taken up by intercultural psychology and which can make a definite contribution to the field of the current projective clinic. In this article, we will first present the foundations of this sub-discipline of psychology, then address the complexity of cultural belonging in the contemporary world, and finally open up new perspectives of projective evaluation in both clinical practice and research. 


\section{Intercultural Psychology: What It Is All About?}

In our multicultural societies, psychologists are often confronted with cultural diversity: migrants, asylum seekers, refugees, but also descendants of migrants. Some of these people have experienced traumatic migratory trajectories, causing them suffering. For most of them, adapting to another culture is not easy because it challenges their relationship with the world, their identity and their values. This intercultural encounter requires them to take into account cultural references that may be contradictory and even sometimes irreconcilable. This reality forces them to make choices that weaken them because they are often a source of conflict at several levels: intra-family, interpersonal and intra-psychic. To deal with these issues, new epistemological and conceptual, but also ethical and deontological thinking have emerged.

More than forty years ago, Claude Clanet and his team introduced at the University of Toulouse le Mirail $^{2}$ a new sub-discipline of psychology "not qualified until then" (Clanet, 2005, p. 113). Its presentation gave rise to a special issue of the journal "Psychology and Education" (1982), followed very quickly by another special issue of the journal Homo XXIV on the person in an intercultural situation in 1984 and publications to make it visible and establish its legitimacy in a French scientific environment, marked by universalist thinking, which was not very inclined to welcome it (Clanet, 1986, 1990; Not, 1986; Clanet, Fourasté \& Sudres, 1993). They will hesitate between two names: cultural or intercultural psychology.

This initiative was created in response to a global context of increasing migration and international exchanges, which are conducive to "interpenetrations of cultures from which difficulties and conflicts arise, which can be identified at all levels: economic, sociological, ideological, scientific, human..." (Clanet, 1982, p. 97). For Claude Clanet, it was therefore necessary to reflect on these intercultural problems, to understand and deal with the dysfunctions generated by cultural contacts, more particularly at the level of the "psychological being" too often forgotten (p. 98). To do this, it was necessary to study the effects of intercultural encounters on individuals and groups, their psychological treatment by identifying the processes and mechanisms involved, the psychological resources mobilized by the subjects to moderate conflicts, or even to overcome them, the forms of identification with different cultural models, the multiple forms of psychological integration between the extremes of assimilation and separation (Krewer and Jahoda, 1993). It was also necessary to question the philosophical and ideological foundations to which French policies refer in order to think about the question of cultural difference and therefore its relationship to otherness. As he pointed out, these policies often constitute "a symbolic violence towards cultural minorities who are asked to assimilate at the risk of marginalization" (Clanet, 1990: 98).

At the beginning of the 1980s, it therefore became urgent to reflect on our multicultural societies which, marked by mistrust of cultural differences, "were secreting defensive attitudes (withdrawal, rejection, closure, over-valuing of the group) that could lead to a clash of cultures" (Guerraoui \& Costa-Fernandez, 2007, p. 167). Moving towards the project of an intercultural society became essential. A society "which, by affirming the need for common norms and languages, is capable of making room for minorities and in which diversity can be perceived as a source of mutual enrichment [...] a society based on the recognition of cultural differences, on the openness of different cultural groups and on the acceptance of change" (Clanet, 1986, p. IX).

It is in a context of crisis at the economic, social and cultural levels that intercultural issues will become the subject of transdisciplinary scientific interest in the human sciences, including sociologists such as Oriol, Demorgon, Wieviorka, Sayad; anthropologists Laplantine, Cuche, Augé; pedagogues Dasen, Perregaux, Abdellah-Pretceille, Tanon, Porcher; political scientists Etienne, Kepel, Schnapper, but also psychologists such as Clanet, Camilleri, Vasquez, Cohen-Emerique, Vermés, Nathan and psychiatrists such as Marie Rose Moro. Bizet (1984), however, doubts the scientific seriousness of the "intercultural phenomenon". For him, the interest shown in these issues would only be ephemeral in a France confronted with the difficulty of integrating the cultural diversity that questions its identity. This point of view was quickly disproved, since at the same time, two international research networks were created at a global level, whose work, to this day, deals with these cultural and intercultural issues: the International Association for Cross-Cultural Psychology (ACCP) ${ }^{3}$, in English, and "Association Internationale pour la Recherche Interculturelle" (ARIC) ${ }^{4}$, in French. Both associations postulate the need to take culture into account in the understanding of psychological functioning, but from different epistemologies, theories and 
methods, which Patrick Denoux (2016) summarises as follows: "their two main orientations have been mainly comparative culturalism for the former and contact interculturalism for the latter, drawing very dissimilar epistemological postures and fields" (p.19). A few years later, symbolic violence against the subaltern, the periphery, was associated with Western modernity, colonialism, and the dominant epistemologies of the North by the Portuguese sociologist Boaventura de Sousa Santos through the concept of Southern epistemology (2011).

The idea of an epistemology of the "South" refers to the decolonisation of knowledge, denouncing the injustice of ignoring, leaving invisible and inferior knowledge, and worldviews of the peoples of the South. According to its author, the South is not a geographical concept, but "a metaphor for human suffering, exclusion and marginalisation on a global scale and the resistance to overcome or mitigate it". (Santos, 2011, p. 16) These studies remind us that there is indeed a "South" for Westernised societies in the Northern hemisphere, Europe in particular, and a "North" with high consumerism, for societies in the South. This perspective is based on the "ecology of knowledge", the idea that there is no knowledge or ignorance in the absolute and on "intercultural translation", understood as "the procedure of creating mutual intelligibility between different experiences of the world, whether available or possible" (Santos, 2011, p. 18). It thus joins the intercultural perspective through the political commitment to the fact that cultures are incomplete and can, therefore, be enriched through dialogue and confrontation with others.

To date, the research in intercultural psychology carried out in France and particularly in the "Interculturation Psychique et Contacts Culturels", section of the Laboratoire Cliniques Pathologique et Interculturelle (LCPI) postulates culture as an antecedent and consequential variable: antecedent because it is the matrix from which the psyche is structured, and consequential because from the intercultural confrontation, processed psychically by the subject, a third culture emerges in which he or she recognises him or herself. A creation resulting from the metabolisation of cultural difference, apprehended from the concept of interculturation which becomes the central research object of this team (Clanet, 1990, Denoux, 1994, Guerraoui, 2009). This orientation invites us, without giving in to cultural determinism, to take into account all the works that favour this link between cultures and psychology, whatever their approaches, thought to be complementary, in order to understand the effects of the intercultural encounter and their psychological treatment. "For these reasons, we (the team members) are working to establish the designation of "intercultural psychology" as a generic term covering the differentialist stance of Cultural Psychology, the universalist tension and relativist scruples of Cross Cultural Psychology, the interculturalist orientation of Culture Contact Psychology, and the grounded stance of Indigenous Psychology" (Denoux, 2016, p.20).

According to this perspective, the psychological subject cannot be understood outside its historical and cultural context. Today, however, this approach is proving to be complex due to the diversity and multiplicity of cultural contexts in which the individual evolves, contexts which contribute to his structuring as a subject. It is therefore impossible, according to this paradigm, to envisage an analysis of the intrapsychic without taking this reality into account.

By positing culture(s) as the matrix(es) from which the psyche is structured, the psychologist is faced with the question of the cultural and the universal in order to understand psychological functioning. Intercultural psychology, based on its various sub-fields, attempts to provide answers for this "understanding of the behaviour of individuals in what they have of universal and/or specific" (Guerraoui, 2011, p. 5).

Cultural psychology answers this question by exploring the role of cultural contexts of actions and interactions on the development of the human psyche. Rejecting all culturalism, it considers culture as a symbolic resource, producer of meaning, constantly manipulated, reinterpreted and re-evaluated by the subject, in the face of a changing reality, through his or her own psychic dynamics, creativity, status, representations and beliefs; a culture that is subjectivised and re-elaborated by the subject.

As for comparative transcultural psychology, its objective is to identify the universality of psychological processes while taking into account intercultural variations, in order to verify the validity of theories of general psychology. But for Sinah (1997), one of the founders of indigenous psychology, this 
aim requires questioning the ethnocentric dimension of psychological knowledge, i.e. the concepts, methods and evaluation tools produced by classical western psychology.

The psychology of cultural contacts focuses on the psychological management of the intercultural encounter by identifying "the psychological, relational, group and institutional processes" (Clanet, 1990, p. 70) that this encounter generates, and by analysing them using the concept of interculturation, which refers to the complex, the paradox, but also to creation. Indeed, closure and openness, resistance and transformation of subjects confronted with multiculturalism are observed. For while they seek similarity, they also wish to differentiate themselves. From these two opposing movements, with respect to the cultural systems in which the subjects structure themselves, a third culture is developed that produces intercultural identities. These identities are constructed not in the rootedness but in the tension between several identity traits. This situation can be experienced by the subjects as destabilising, conflicting and generating a psychological insecurity which is a source of vulnerability. Indeed, the integration of multiple values, norms, rules and practices can be the source of uncertainty and ambivalence about the definition of oneself and one's relationship to the world and to others. The psychological adjustments that mobilise affects and defence mechanisms can be costly. The links between the different symbolic systems can be problematic and be the cause of addictive behaviour, decompensation and psychological disorders.

Faced with these realities, several questions arise for the researcher and the practitioner, namely How to apprehend the intercultural variation of psychological functioning? What conceptual and methodological tools should be used in professional practice and/or in research?

\section{The Complexity of Cultural Belonging in Contemporaneity}

We start from the premise supported by Hall (2009) that the transition from modernity to postmodernity is characterised by the emergence of hybrid identities and individuals who claim multiple cultural affiliations (p.57). In our complex societies, with porous, fluid boundaries (Bauman, 2000) a banal cosmopolitanism is imposed with the emergence of "the border man, torn between the transnationalism of mobility and the violence of walls". (Agier, 2015, p.80).

In a world in transformation, intercultural psychology, more particularly its sub-field "Psychology of cultural contacts" based on the processes of interculturation, helps us to understand new modes of psychological functioning. It offers us theoretical and methodological tools for analysing the processes generated by intercultural encounters and the challenges of otherness. At the individual level, as underlined above, she reminds us of the paradoxical character of the processes mobilised by the subject to psychically manage the cultural pluri-referentiality from which he has structured himself. A plurality of cultural traits such as values, beliefs, representations, behaviours, are reinterpreted, subjectivised, and combine and interact with each other. All these elements interfere within the structure of the personality, forged in childhood and over time under the influence of relationships, the social and cultural environment (Bergeret, 1985).

These processes give rise to a singular dynamic that cannot be reduced to any of the cultural poles in which the person evolves, a reality reflected in the concept of interculturation. This concept highlights the complex character of the structuring of the personality of the intercultural subject who differentiates himself while at the same time being in tune with the other members of the cultural groups to which he refers. Thus, through cultural assimilation and differentiation, he or she proceeds to a real creative crossbreeding, elaborating his or her own inter-structurations. This structure, which is built in intrapsychic tension, favouring ambivalence over cleavage, relies, in order to maintain its coherence and unity, on the psychological resources mobilised by the subject, particularly in the form of identity strategies (Camilleri, 1990). These strategies, simple or complex, associated with defence and release mechanisms such as denial, rationalisation, projection and sublimation, allow the subject to manage the differences between the symbolic codes, identification models and norms proposed by the different cultural reference systems while adapting to a multicultural environment.

The relevance of this approach has become obvious today due to the cultural mutations that our living environments are undergoing, as a result of migrations, but also with the transition from the analogue to the digital world and the hegemonic use of Information and Communication Technologies (ICT) (Costa- 
Fernandez, \& Donard, 2016; Costa-Fernandez, 2018), without forgetting mobility, which has become "a virtuous social capital to possess in our present societies" (Delaunay \& Fournier, 2014, p. 131).

All current work in intercultural psychology shows that the encounter with otherness imposes a permanent negotiation between interactants to define what is common and tolerate differences (CostaFernandez, Denoux \& Lescarret, 2018). This look at otherness thus allows us to think about the issues and the complexity of cultural diversity, including that of the cohabitation of identities, which is only made possible through the reciprocal recognition of individual, cultural, linguistic and contextual particularities. This complexity is the result of what Hannerz (1992) calls cultural flows, which are not only linked to migration, but also to exchanges via the "new" communication technologies and the interconnection of economic and political systems.

Because of these realities, the interest in reflecting on assessment in an intercultural situation is not limited to specialists working with minorities, migrants or children from transnational families. It is a reflection that is necessary to understand "the psychic reality of contemporary subjects who are all bearers of this complexity" (Sturm, Bonnet, Coussot, Teyssié, \& Raynaud, 2017, p. 171). Thus, cultural diversity can no longer be thought of as the simple multiplication of the number of cultures found in a given place, but refers to a growing complexity, described by anthropologists as "the transformative diversification of diversity" (Vertovec, 2007, p.1024).

So, Guerraoui and Reveyrand-Coulon (2013) ask themselves, how can we encourage the emergence of the creative potential of the intersection of multiple affiliations, be it at the level of family, cultural or religious filiations and affiliations? What strategies should be used to address the risks involved in both prevention and screening? What mechanisms should be applied in the assessment, therapeutic follow-up and results feedback phases? How can we avoid this complexity accentuating existing vulnerabilities? These questions, which are important for prevention, assessment and therapeutic interventions, "require not only epistemological and conceptual reflection, but also ethical and deontological reflection that leads the psychologist to question his or her practice, to question his or her techniques and methods of intervention and sometimes also to adapt his or her tools" (Sturm, Guerraoui, Bonnet-Samitier, Gouzvinski \& Raynaud. 2017, p. 445).

What about projective tests? Are these tools culture-free as many psychologists claim? Depending on the culture(s) and language(s) used during the test, does the subject reveal the same mysteries of his or her psyche? Are our evaluation and interpretation grids appropriate and adaptable transculturally? These questions are all the more justified when we are faced with subjects who have evolved in a plurality of cultural references. How can we apprehend this (these) psychological reality(s), so frequent nowadays, through our psychological tests?

\section{New Perspectives on Projective Assessment in Clinical Practice}

In a globalised world, marked by mobility and multiple cultural references, the use of Information and Communication Technologies (ICTs) would reinforce the standardisation of behaviour, practices and values. But alongside these homogenising tendencies, there is the "subaltern proliferation of difference" (Hall, 2009: 57). So how do we understand the effects of multiple affiliations on the individual? What clinical assessment devices would be most adaptable across cultures? What tools could contribute to the analysis of what happens when a subject changes language, culture and context? How can we take into account the plurality of cultural affiliations of the contemporary subject and prevent the risks of cleavage, and treat his or her sufferings? In the clinic, understanding the plurality of cultural affiliations of the subject is a privileged way of reaching his singularity. This approach becomes essential in the construction of innovative and creative solutions and offers the psychologist a field of new information (Daure, 2010). So, what projective tools should be used, what methods of analysis should be used, what adjustments should be made and what perspectives should be adopted for intercultural situations?

Clinically, the intercultural has been one of the seven major areas of concern in the publications of the "Rorschach Society", with work on populations that can be described as 'colonial' (Roman, 2003, p.20). In the 1990s, the first works on the use of projective tests in intercultural situations questioned the aims, the biases, the challenges to be overcome and the strategies to be favoured in these situations of cultural contact. 
The publications no longer looked for the particularities of certain "exotic" populations but rather for the gaps in the "in-between". Some of the published cases emphasised "the importance of distinguishing the cultures of the three terms of the clinical encounter, namely, the culture of the psychologist, that of the tool and that of the subject being assessed" (Costa-Fernandez E., 2011, p.194). In other words, it was a question of questioning whether the psychologist and the subject share the same language, the same representations and the same values. But also that of the tool, insofar as any test is conceived as the application of a given theory, of a certain epistemological model, according to a certain methodology, in a language shared or not by the actors involved. This points to the fact that tests, like people, are culturally marked. (Guerraoui \& Pirlot, 2011)

Two kinds of professional situations are therefore considered intercultural in order to confront the clinician with cultural diversity: interventions in the host country, with a migrant population, and situations of professional expatriation, where the psychologist finds himself or herself and his or her tools a stranger, most of them designed and standardised for a Western population. These situations synthesise the three levels of interculturality proposed by Dérivois (2009), namely "interculturality of migrant populations, interculturality of practitioner-researchers \& interculturality of theories, models and concepts" (p.64).

To this is added another question concerning the reference to "local" norms. Are they sufficient to take the cultural into account, or do we need to create new tools, to reinvent the devices according to the situation? The recommendations for the practice of psychological examination and the use of measures in child psychology drawn up by the Consensus Conference in $2010^{6}$ recall that the psychologist must always remain attentive to the complexity and singularity of the person, situated in his or her family, educational, social and also cultural context. But how can we model and take into account these precautions in our interventions?

We consider that taking into account cultural diversity in psychological intervention in situations of cultural contact should be based on three principles: "the confrontation between the cultural representations of the person and those of the psychologist; the taking into account of the cultural counter-transference of the psychologist and the questioning of the methodological and conceptual knowledge of the professional, i.e. his or her decentration". (Costa- Fernandez \& Tran Thu., 2013, p.139)

When the psychologist does not share the same culture, the same language, with a migrant subject with multiple cultural affiliations, the aim of the intervention must bring out, through verbalisation and elaboration, the contradictions and paradoxes of the different cultural references. It is also a question of encouraging the overcoming of conflicts caused by the gap through "the affirmation of the singularity of the person and his or her adaptation to plural constraints and demands". (Costa-Fernandez \& Tran Thu., 2013. P.145) All this does not exclude the cultural decentring necessary for any assessment or psychological care process, including for subjects who a priori share the same culture.

\section{Two Examples of the Use of Culture-Proof Projective Methods in the Field of Research}

After these considerations on the use of projective tests in clinical intervention, two studies illustrate their use in research. These are not comparative studies, but rather two attempts to understand what is at stake in the cultural in-between. The proposed research aims to analyse the psychological mechanisms at work when the subject is confronted with a major intercultural situation. Each of the investigations, thanks to the projective, reveals the specific defensive and release modalities and especially the psychological movements of interculturation underlined before. For one, the question of the differentiated use of languages is explored through the double TAT test. For the other, the issue of identity belonging is proposed through the Rorschach of sedentary and migrant members belonging and referred to the same Bassari ethnic group (Senegal). For each study, the use of the projective tool is put at the service of new situations.

\section{Double-Testing of the Thematic Apperception Test (TAT) With Bilingual Subjects}

An example of research carried out using projective methods was the use of the TAT with a population of Brazilians living in France. This study ${ }^{7}$, initiated at the beginning of the 1990s, illustrates in a particular way the importance that must be given to the status of the language during the taking of a projective test. 
Is it the migrant's mother tongue or a language with the status of a second language because it was learned late in life? (Costa-Fernandez, 1991 p. 15).

The researcher assumes that a language is much more than a code. "Speaking a language implies the implementation of specific defensive procedures, with consequences on the processes of symbolisation and on the integration of the self". (Costa-Fernandez, 1991, p. 128) Expression in a second language would therefore imply changes in relation to the mother tongue. These changes would come from new social and cultural representations acquired during the migrant's integration into the host society, but not only. Unconscious elements associated with the initial function of the mother tongue in the psyche must be taken into account.

"From a psychoanalytical point of view, the archaic mother tongue is the one that introduces the subject to the Other and holds the prohibition of incest within itself" (Hassoun, 1979, p. 35). From this perspective, the alternating use of the two languages by a bilingual subject would serve as a privileged means of understanding the individual strategies adopted in the face of the ruptures of migration. Consequently, the double passage of the same projective test makes it possible to apprehend the gap between the problems (contents) and the defence mechanisms (formal procedures) put in place during expression in the mother tongue and the second language.

The research methodology is qualitative, consisting of a semi-directive interview on the life history and migration trajectory of ten Brazilians living in France for more than five years. Then the (TAT) was offered to each volunteer in their native Brazilian Portuguese and in French as a second language, six weeks apart. The data obtained from the interview was then cross-checked with the data obtained through the parallel between the two passages, in three stages: analysis by board, analysis by pair of stories and synthesis.

The results obtained confirm that the migrant's behaviour varies according to the languages used and this through the difference between the issues and the formal characteristics of the two passages. Both the content of the narratives from the TAT sheets and the formal procedures identified by the analysis grid (Shentoub et al., 1990) in the mother tongue vary when he expresses himself in the second language (CostaFernandez, 1991, p. 291).

Our conclusions show that the mother tongue and the second language are opposed in the way they represent the Oedipal phantasmatic. The mother tongue, through which the child has learned to speak, founds the superego, the prohibitions and the guilt, and remains the inaugural language. As a primary mediator, its role is complementary to that of the second language, the paternal language, associated with the discovery of the other and allowing the invention of the self.

The second language, acquired late, conveys new collective ideals. Faced with the absence of an ego ideal that is sufficiently structured and adapted to the new culture, the migrant will tend to replace it with the ideal ego, an instance of personal power. The second language arouses the anxiety of fragmentation, to which the subject reacts with specific defensive mechanisms. At the level of formal procedures, the weakening of the ego will allow the emergence of primary factors, hence the fall in readability of the narratives.

It thus emerges that in intercultural situations, the practice of a second language would be analogous to a place of "disturbing strangeness" for the subject who would lose the representational nuances of his emotional keyboard. However, in other cases, "this second language appears, on the contrary, as liberating since it is less controlled and thus provides the subject with a privileged way of expression and elaboration". (Pirlot, Costa Fernandez, Guerroui \& Cupa, 2011, p.434).

The application of these conclusions to the psychological examination of the bilingual child implies that we must decentralise ourselves from the tool in order to take an interest in the clinic of the subject being tested. The first precaution for the clinician is to check the status of the language used by the child during the projective tests and the interview.

This study from the 90ies retains its methodological originality and is in line with other scientific work for which culture is not a static and immovable element, a tendency which leads in particular to underestimating the impact of life events and the context. According to Couchard (1999), migration always imposes a series of psychic rearrangements that will modify the migrant's relationship to his or her culture (language) of origin and lead to various forms of integration or acculturation. However, some psychologists 
neglect this aspect, claiming that a psychological examination provides valuable information on the subject's psychological and cognitive functioning, regardless of his or her cultural background and mother tongue. Ideally, in our opinion, a comparison of a migrant's output in each of his or her languages should be made. The alternate use of languages and the parallel of their productions are meaningful.

\section{The Rorschach, in a Faraway Land, to the Test of Interculturation}

The Rorschach was chosen by Odile Reveyrand-Coulon (1989) from a research perspective, detached from its clinical diagnostic function. Its objective is to reveal the tendencies of the psychic organisation of two migrant and sedentary groups linked by their belonging to the Bassari ethnic group,

The Bassari, a "traditional", matrilineal, strongly animist culture, live in a remote region of eastern Senegal. Some of them migrate to Dakar. The researcher starts from the hypothesis that the act of migration mobilises defensive and adaptive mechanisms, present in, or developed by, the migrant subject. Because of the profound change in the lives of the Bassari migrants, she maintains, like C. Chabert, that 'the Rorschach will allow for an elaboration of the perception according to the essential concerns of the subject, (...) while soliciting the mechanisms of adaptation to reality" $(1984, \mathrm{p} 13)$.

This investigation contains three central aspects of the intercultural problematic. Firstly, it is a question of making use in another culture of a tool forged in Western society ${ }^{8}$. Secondly, it aims to identify the processes of psychic adjustment of migrants situated between two cultures. Finally, the clinician-researcher and anthropologist, referring to the paradigm of dynamic psychology, carrying another culture than the one of the persons met, must - herself placed in an intercultural situation - adjust the projective test (examples: when it is not possible to conduct the test in a face to face meeting).

As the Rorschach offers the possibility of identifying the modalities of autonomy and security with regard to the lost object, and the capacity to confront the anxiety-provoking external world, it seemed appropriate to use it in an intercultural situation. Nina Rauch de Traubenberg et al (1988), working with Vietnamese adolescents, state that they wanted to: "highlight the singularity of psychological functioning, on the one hand as a function of cultural specificity, and on the other hand as a function of the possible repercussions of the traumas linked to the conditions of transplantation" (1998, p. 98).

The test was administered in French or Bassari. The vast majority - even among those who speak French well - chose Bassari. As for the time taken to complete the test, there was a clear difference between the two groups: between 10 and 15 minutes for the "sedentary" group, and between 45 minutes and one hour for the "migrants".

Another originality of this work is that, although the test was carried out individually, due to the high number of protocols (105), the data analysis was carried out using a lexical analysis process, the Alceste method (Reiner, 1988). This statistical method is not based on accumulations, but on variations, presences and absences of text segments, their similarities or differences.

The descending hierarchical classification reveals classes that are inferred from each other. Some final classes included items clearly associated with the indicators "sedentary" for some and "migrants" for others, revealing contrasting psychological trends. Numerous dimensions were identified, including socialisation factors and indicators of object investment patterns, as indicated by the determinants $\mathrm{F}$ and $\mathrm{K}$, which show differences between the two groups.

The "sedentary" class contains exclusively $\mathrm{F}+$ as well as an important part of $\mathrm{C}$ (color) and $\mathrm{K}$ (kinesthesia). This may be a sign of dependence and conformity, a manifestation of strong adhesion to the group to which they belong. Let us underline the quasi absence of human content and of there of human kinesthesia, whereas animals and Kan are largely present.

The class comprising the migrants presented a high percentage of $\mathrm{F}$ - to the detriment of $\mathrm{K}$ and $\mathrm{C}$, suggesting a bad perceptive identification of the engram and the evacuation of impulses and affects. In addition, the multiplication of details and supporting data may be a sign of anxiety. There, a few rare "suffered" Kh, passive position, were repeated, without any aggressive expression, except in an implicit way by animal "devitalizations".

The analysis of the protocols suggests that the migrants (unlike the sedentary ones) mobilize psychological mechanisms essential to their adaptation in a socio-cultural environment radically different 
from their initial living environment, which would allow them to free themselves from the accentuated dependence on their community culture, to assert themselves subjectively, to face the conflictualities underlying the migratory movement, to mobilize potentialities in front of the unknown.

Finally, three important variations appeared in relation to the classically accepted ratings. Firstly, instead of "expected" banalities, a sign of adapted functioning, we found modified banalities (P1.I bat, P1.II blood, female, P1.III two characters, blood, P1.IV tree, P1.V bat, rabbit, bird, P1.VI skin, turtle, P1.VII cloud, butterfly, P1.VIII chameleon, P1.IX plant, P1.X tree). Then, instead of G answers and then Dd, we found in all the boards the apprehension of the perception of the Dd before the G. Finally, as far as the content of the answers is concerned, we note the omnipresence of the animal, the vegetable and even the water to the detriment of the human.

The intercultural perspective, through the Rorschach, makes it possible to apprehend the adaptive modifications (or not) of the subjects. Moreover, it forces us to decentre (Daure, Reveyrand-Coulon, 2019) and to admit that the mode of perception of the task and the narrative construction of the task would be part of another way of apprehending the world, which is put to the test in intercultural situations.

The two examples of research presented illustrate intercultural devices created according to the particularities studied. What they have in common is the relevant and innovative use of a projective test in intercultural situations. On the one hand, each in a specific way, seizes, not without questions and with audacity, this intercultural problematic and takes advantage of the projective tests to understand subjects in intercultural situations. On the other hand, each one is led to re-interrogate certain aspects specific to the "projective" tool (passing, methods of analysis), exploring the importance of language and the interpretative procedures. Here and there, we find the psychology-culture combination highlighted above.

\section{CONCLUSION}

In the early 1990s, Daniel Sibony (1991) proposed to replace the concept of "difference", which he considered insufficient to account for major identity-related, subjective and collective discomforts, by the concept of "in-between", which defines the places and moments through which one passes in order to become different and attempt to make something of "one's" difference. These varied contexts thus become sites of passage or dead ends, depending on whether the origin that is replayed in this ordeal proves to be accessible or not to some kind of sharing. These "in-between" spaces, which guarantee transitionality, have appeared in contemporary times as the support of intercultural processes. (Clanet, 1990; Denoux, 1994, p.67).

In a hybrid world, with plural cultural references but invaded by hegemonic socio-cultural practices, we are entitled to ask ourselves whether or not the world's cultural diversity is in danger. Increasingly frequent migratory movements, mobility and nomadism, and the growing number of transnational families are giving rise to linguistic dynamics with multiple cultural affiliations for which the question of the place, function and investment of each language that the subject uses in his or her daily life must be raised. Convinced of the limitations of comparative approaches in a globalised world where, instead of confronting each other, cultures tend to mix and merge, what would be the aims of psychological evaluation? By what means can projective tests contribute to the apprehension of the complexity of interculturation processes?

If it is relevant to question the interpersonal stakes of the psychologist's clinical practice in an intercultural context, it is even more important to question the devices and strategies designed to prevent and counter them. Projective tests still have a role to play in the work of integration between the individual and the collective, even if this place remains to be reinvented in the contemporary world.

\section{ACKNOWLEDGEMENT}

Translated \& Edited by American Publishing Services (https://americanpublishingservices.com/). 


\section{ENDNOTES}

1. Published in French in "Psychologie clinique et projective 2020/1 ( $\mathrm{n}^{\circ} 27$ )" pages 35 to 54, traduction authorized by the review.

2. On 26 March 2014, the Board of Directors of the University Toulouse II-le Mirail voted unanimously to change its name to Toulouse Jean-Jaurès. This change of name is part of a process of refoundation and reconstruction of the university.

3. http://www.iaccp.org

4. http://www.aric-interculturel.com

5. Cross cultural psychology, to which we add the comparative qualifier, covers all fields of application (clinical, social, cognitive, developmental, etc.). It refers to the need to articulate the universal and the specific by identifying the general laws of psychological functioning while taking into account cultural variation.

6. The French Federation of Psychologists and Psychology (FFPP), in association with the French Society of Psychology (FSP), the French Association of National Education Psychologists (FANEP) and the Association of French Guidance Counsellors-Psychologists (FGCP), organized a Consensus Conference, with the objective of producing a set of argued recommendations constituting the essential criteria of quality of the child psychological examination. The organising committee, under the direction of Jacques Grégoire, set up six working groups whose mission was to produce a synthesis of current knowledge on the subject, each of them being responsible for analysing in depth one facet of the psychological examination.

7. Doctoral thesis "Becoming a subject between two languages. The acquisition of French as a second language by Brazilians living in Toulouse" defended by Elaine Costa Fernandez under the supervision of Claude Clanet in 1991 at the University of Toulouse le Mirail

8. Rorschach proposed to test his test by comparing cultural groups. In "Comparative Research and Type of Experience" he explains: "The typical experience must be different for different peoples and races. (...) This difference must be even greater if the racial difference is greater. The test is technically so simple that it can be administered with the help of an interpreter to the most primitive Negro as well as to a cultured European" (1921, p. 96). Hence his famous comparative experiment between two Swiss cantons, Bernese and Appenzeller!

\section{REFERENCES}

Agier, M. (2015). Migraçōes, Descentramentos e Cosmopolitismo: Uma antropologia das fronteiras. Tradução de Bruno César Cavalcanti, Maria Stela T. B. Lameiras e Raquel Rocja de A. Barros. São Paulo: Edufal, Editora UNESP.

Bauman, Z. (2000). Liquid Modernity. Cambridge, Polity Press.

Bergeret, J. (1985). La Personnalité normale et pathologique. Paris, Dunod.

Berry, J.W. (1997). Immigration, acculturation and adaptation. Applied Psychology: An International Review, 46, 5-68.

Bizet, J.A. (1984). L'«interculturel »: Problématique de recherche ou thème journalistique. In Les dossiers de l'Education (N. 4). Toulouse PUM.

Camilleri, C. (1990). Identité et gestion de la disparité culturelle : Essai d'une typologie. In C. Camilleri et al. (Eds.), Stratégies identitaires (pp. 85-110). Paris: PUF.

Chabert, C. (1988). Le Rorschach en clinique adulte : Interprétation psychanalytique. Paris: Dunod.

Clanet, C. (1982). Un DESS nouveau Actions de formation en situation interculturelle. Psychologie et Education, 2(VI), 97-109.

Clanet, C. (1986). Avant-propos, L’interculturel en éducation et sciences humaines. Toulouse, PUM, pp. IX-XI.

Clanet, C. (1990). L'interculturel. Introduction aux approches interculturelles en éducation et sciences humaines. Toulouse: PUM, coll. Interculturels.

Clanet, C. (2005). Psychologie, éducation et changement culturel. In G. Vaysse (Ed.), 50 ans de Psychologie à Toulouse (pp. 113-140). Toulouse, PUM.

Clanet, C., Fourasté, R., \& Sudres, J.L. (Eds.). (1993). Corps, cultures et thérapies. Toulouse, PUM. 
Costa-Fernandez E., Denoux P., \& Lescarret O. (2018) Mobilités, Réseaux et Interculturalités. Nouveaux défis pour la recherche scientifique et la pratique professionnelle (p.317). Paris Harmattan.

Costa-Fernandez, E. (2018). Diversité culturelle et stratégies identitaires sur les Forums de discussion de migrants sur le Web. In A.D. Lezou Koffi (Dir.), Diversité et Dialogues en Questions. Des réalités complexes (volume 1, pp. 159-168). Abidjan: Editions Universitaires de Côte d'Ivoire.

Costa Fernandez, E.M., \& Donard, V. (Eds.). (2016). O Psicólogo frente ao desafio tecnológico: Novas identidades, novos campos, novas práticas. Recife, Brésil: Editions UFPE et UNICAP.

Costa-Fernandez, E. (2016). NTIC: Globalização, democratização e diversidade cultural. In E.M.C. Fernandez \& V. Donard (Eds.), O Psicólogo frente ao desafio tecnológico. Novas Identidades, novos campos, novas práticas (1st ed. v.1, pp. 17-36). Recife: Editora Universitária UFPE/ UNICAP.

Costa-Fernandez, E. (2011). L'évaluation psychologique en situation interculturelle. In Z. Guerraoui \& G. Pirlot (Eds.), Comprendre et traiter les situations intercultuelles. Approches psychodynamiques et psychanalytiques (pp. 193-209). Bruxelles, De Boeck.

Costa-Fernandez, E., \& Tran Thu, H. (2013). Des études de cas issus d'une coopération internationale entre la France et l'Asie du Sud-Est. In M. Laaroussi-Vatz et al. (Eds.), Les défis de la diversité. Enjeux épistémologiques, méthodologiques et pratiques (pp. 139-152). Paris : L'Harmattan,

Costa-Fernandez, E. (1991). Devenir sujet entre deux langues, Les effets psychologiques de l'acquisition du Français, langue seconde, chez des brésiliens vivant à Toulouse. Thèse de doctorat, Université Toulouse 2.

Couchard, F. (1999). La psychologie clinique interculturelle. Collection les TOPOS, Paris, Dunod.

Daure, I. (2010). Familles entre deux cultures : Dynamiques relationnelles et prise en charge systémique Paris : Fabert.

Daure, I., \& Reveyrand-Coulon, O. (2019). Le migrant et sa famille. Défis interculturels en psychologie clinique. Paris, Esf.

Delaunay, D., \& Fournier, J. (2014). Mesurer le capital de mobilité pour évaluer les différenciations sociodémographiques et intra-urbaines de l'accessibilité : Le cas de la zone métropolitaine de Santiago du Chili. Revue Tiers Monde, 218(2), 131-149.

Denoux, P. (2016). Préface in E. Regnault E et E. Costa Fernandez. L'interculturel aujourd'hui Perspectives et enjeux (pp. 19-26). Paris Harmattan.

Denoux, P. (1994). Pour une nouvelle définition de l'interculturation. In J. Blomart \& B. Krewer (Eds.), Perspectives de l'interculturel (pp. 67-81). Paris, Ecole Normal Sup de St Cloud/L'Harmattan.

Guerraoui, Z. (2009). De l'acculturation à l'interculturation : Réflexions épistémologiques. L'Autre, Clinique, Cultures et Sociétés, 10(2), 195-200.

Guerraoui, Z., \& Costa-Fernandez, E. (2007). De la nécessité de la psychologie interculturelle en clinique. In A. Savet \& J.P. Martineau (Eds.), La formation professionnelle des psychologues cliniciens et l'université (pp. 166-172). Paris : l'Harmattan.

Guerraoui, Z., \& Pirlot, G. (2011). Comprendre et traiter les situations interculturelles. Approches psychodynamiques et psychanalytiques. Bruxelles : de Boeck.

Guerraoui, Z., \& Reveyrand-Coulon, O. (2013). La méthodologie en psychologie interculturelle. Les Cahiers Internationaux de Psychologie Sociale, 3, 99-100, 291-294.

Hall, S, (2009). Da diáspora: Identidades e mediações culturais (1 éd.). Belo Horizonte: Editora UFMG.

Hannerz, U. (1992) Cultural Complexity, Studies on the Social Organisation of Meaning. New York, Columbia University Press.

Hassoun, J. (1979) Fragments de langue maternelle - esquisse d'un lieu. Paris : Payot.

Not, L. (Ed.). (1986). Regards sur la personne. Toulouse, PUM.

Pirlot, G., Costa-Fernandez, E., \& Guerraoui, Z. (2011). Réflexions sur l'usage de langues dans l'évaluation psycho(patho)logique appliquée à la création littéraire 2. In S. Beckett, J. Green, \& V. Nabokov, Evolution Psychiatrique (volume 76, pp. 433-447). 
Rausch de Traubenberg, N., Bloch-Laîné, F., Boizou, M.F., Martin, M., \& Poggionovo, M.P. (1988). Etude psychologique des adolescents vietnamiens. Apport du Rorschach. Spécificité culturelle, vécu traumatique, modalités d'adaptation. Enfance, 41(1), 95-104.

Reveyrand-Coulon, O. (1989). Stratégies individuelles et contraintes collectives. Approche psychologique et anthropologique de la migration des Bassari (Sénégal Oriental) à Dakar. Thèse d'Etat, Université Toulouse 2.

Reiner, M. (1988). Un logiciel d'analyse lexicale (Alceste). Cahier d'analyse des données, 4, 471-484.

Roman, P. (2003). Cinquante ans de publications de la «Société du Rorschach». Psychologie Clinique et Projective, 9, 19-28.

Rorschach, H. (1921). Psychodiagnostic (7e éd.). PUF.

Santos, B. de. S. (2011). Épistémologies du Sud. Études Rurales, 187, 21-49.

Shentoub, V. (1990). Manuel d'utilisation du TAT. Paris : Dunod.

Sibony, D. (1991). Entre-deux : L'origine en partage. Paris : Seuil.

Sinha, D. (1997). Indigenizing psychology. In J.W Berry, Y.P. Poortinga, \& J. Pandey (Dir.), Handbook of cross-cultural psychology (pp. 459-463). Boston: Allyn \& Bacon.

Sturm, G., Bonnet, S., Coussot, Y., Teyssié, M., \& Raynaud, J. (2017). Connexions transnationales et dynamiques familiales. L'impact des nouvelles technologies sur la communication et les liens dans les familles en situation de migration. Cahiers Critiques de Thérapie Familiale et de Pratiques de Réseaux, 58(1), 171-187.

Sturm, G., Guerraoui, Z., Bonnet-Samitier, S., Gouzvinski, F., \& Raynaud, J.P. (2017). Adaptations within a child and adolescent psychiatry department to the needs of children and families with complex migration experiences: The Toulouse University Hospital's intercultural consultation. Transcultural Psychiatry, 54(4), 445-465.

Vertovec, S. (2007). Super-diversity and its implications. Ethnic and Racial Studies, 30(6), 1024-1054. 